\title{
RANKING OF PRIORITIES AMONG THE BALTIC CAPITAL CITIES FOR THE DEVELOPMENT OF SUSTAINABLE CONSTRUCTION
}

\section{Marius Lazauskas, Edmundas Kazimieras Zavadskas, Jonas Šaparauskas}

\section{Introduction}

The financial crisis that commenced in 2007 and peaked in 2008, destabilised the real estate market. Changes in credit policy deprived property owners of their ability to settle accounts with banks [13], [2], [11], [21], [1]. The construction sector was not the only one that fell victim to the economic downturn as it took its toll on other industries as well [13].

Construction is among the most significant sectors that impact on the level of national economics [29]. Likewise, the prevailing international and national situation caused fluctuations in the field of constructions; consequently, the latest period of crisis in the construction industry not only affected Western economics but also spread to the Baltic states, including Lithuania. The end of 2013 - the beginning of 2014 saw the start of the recovery of the Lithuanian construction sector. Just like many other countries of the world, Lithuania implements numerous projects constructing buildings and complexes of the new type of quality, this way improving the condition of buildings nationwide. Qualitative and quantitative urban development takes place in historic city centres, residential areas, unused territories or currently dilapidated public areas that could be revived for the benefit of residents or other stakeholders.

Aiming to resolve issues related to the crisis of the real estate sector as well as attempting to stabilise the situation in the region, actors of Baltic construction sectors revisited their business priorities and objectives. It is only natural that Lithuania, Latvia and Estonia have distinctive construction sector traditions of their own that reflect different aspects pertaining to economics, market, legal framework, technologic and technical solutions, culture, psychology, etc.
Generally speaking, however, the success of the construction sector is determined by legal regulation as well as institutional and political strategies of a country [12].

Stabilisation of such economic and financial processes of the Baltic region as enterprise bankruptcy, unemployment rate, growing numbers of bad loans, falling wages and prices of real estate urged actors of the real estate market to assess their way forward.

Tight cooperation between the Baltic states on the level of governments as well as joint activities of separate actors of the construction market necessitate the assessment of the largest cities of Lithuania, Latvia and Estonia from the point of view of potential construction sector markets that should be mostly considered for effective development of construction projects. Investigation into the construction sector potential of three Baltic state capital cities (Vilnius, Riga and Tallinn) would facilitate an expedient targeting of capital and investments of construction market actors in order to create the greatest added value of national economics, residents and the development of sustainable environment.

A large number of fields, which impact on the development of a sustainable city, belongs to the construction industry, including new property development, adaptation of old buildings to contemporary needs, construction of roads and engineering networks, and integration of renewable energy technologies in buildings. In the assessment of urban development, the construction field must encompass architectural, environmental, social and economic aspects to ensure the result that will be suitable for current and future generations of residents. A complex model is required for modelling of a contemporary city, on the basis of which it would be possible to analyse urban development and the future 
sustainable development planning using modern technologies and strategic decisions.

Looking at a number of alternatives that are described using distinctive criteria, it is rational to use multi-attribute assessment methods. MOORA (Multi-Objective Optimisation by Ratio
Analysis) and MULTIMOORA (MOORA plus Full Multiplicative Form) methods are used to address this particular problem related to the assessment of priorities among cities of Vilnius, Riga and Tallinn in terms of the development of sustainable construction ideas.

\section{Tab. 1: SWOT analysis of the Baltic states}

\begin{tabular}{c|l}
\hline SWOT & \\
\hline & Macroeconomic stability; \\
& Continuous economic growth; \\
Geographically advantageous position, focused on the transit in the western direction; \\
\hline Focus on western markets; \\
High level of education; \\
Access to the Baltic Sea.
\end{tabular}

\section{Relevance of Issues Particular to the Baltic States}

Sustainable development is among the key concerns of the contemporary world. Possibly, the greatest part of issues related to the process of sustainable development is associated with social needs of residents and their attitude toward the surrounding environment as well as nature [5]. The community, businesses, public institutions and governmental authorities are joining forces to find ways and promote the economic development as well as environmental and social well-being in the attempt to satisfy natural needs of people [20]. Therefore, cooperation between business representatives and the public sector is essential in order to implement the most effective solutions. All parties of a construction project development aim to achieve their own objectives. This is the reason why entities operating in the Baltic Sea Region and offering constriction services and products are concerned with investments into the most effective markets.

Aiming to assess attractiveness of a certain object, all entities of the public and private sectors seek to determine its strengths, weaknesses, opportunities and threats, i.e. to carry out the SWOT analysis. The Baltic states have many similarities; thus, general essential SWOT parameters can be defined (Tab. 1).

Subsequent to the assessment of general attributes of strengths, weaknesses, 
opportunities and strengths, a conclusion can be made that all countries face similar issues in social, industrial, strategic and other fields; consequently, similar problem solving methods can be used to support these markets. The objective of the formulated problem is to determine, which of the analysed capital cities is the most attractive in terms of investments into fields of the construction industry and in which of them the investment process would ensure the greatest added value through sustainable development.

\section{Designing the System of Criteria}

Effective development of construction projects must be based on confidence regarding the successful completion of a project and realisation of set objectives that are as close to the sustainable development policy as possible. As potential markets for the implementation of construction objectives, cities are made of numerous descriptive criteria. Three alternatives have been assessed in this particular case: Vilnius, Riga and Tallinn. These three capital cities are described using criteria, such as density of population, the number of public transport routes, average wage of working population, the Global City Competitiveness Index, the price for purchase or rent of residential or office space, health care index, etc. Authors of this article identified there main groups of criteria (economic, social and environmental), which are used in this article to assess effectiveness of a city (Tab. 2).

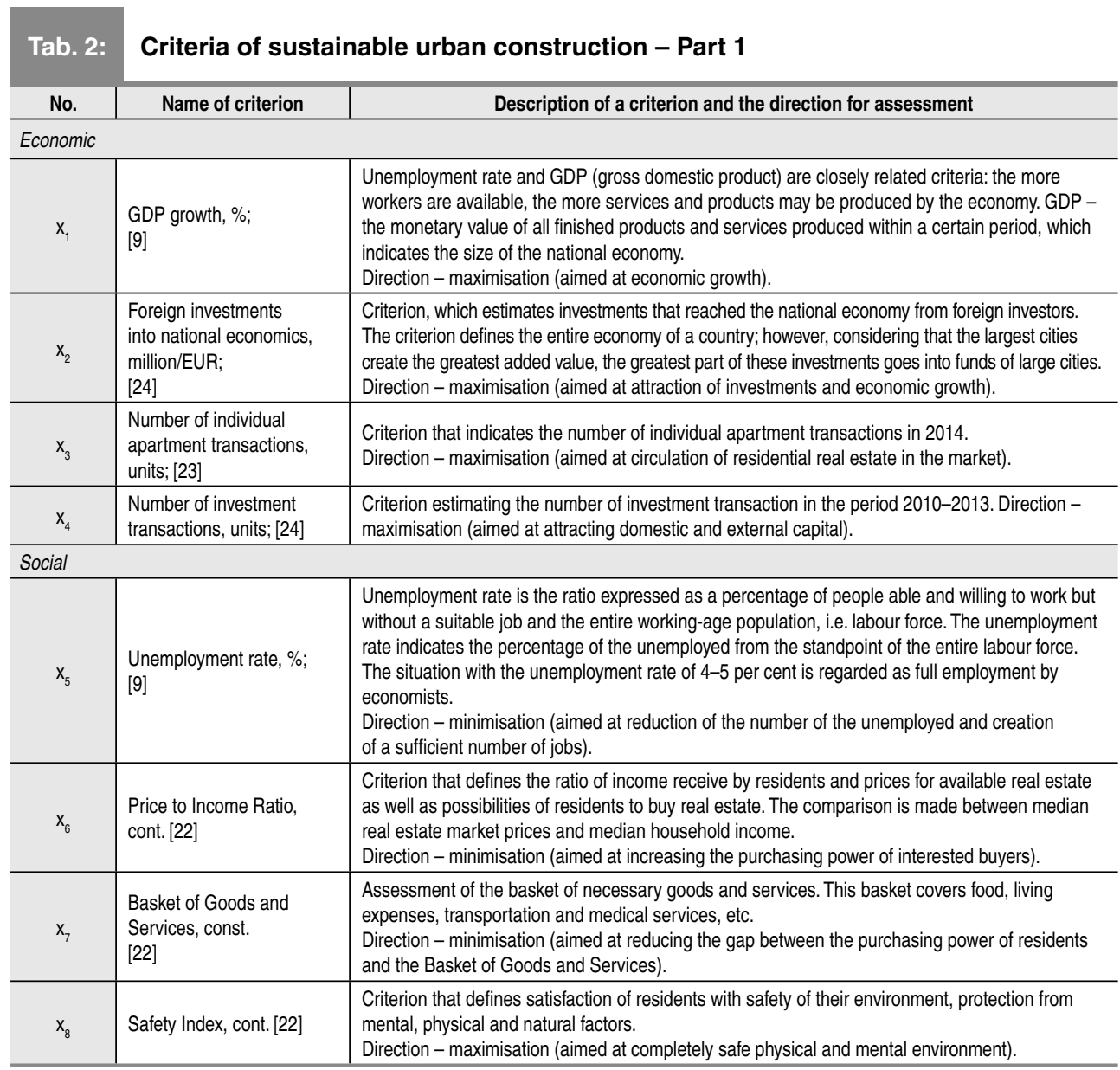

Source: own and [9], [22], [23], [24], [31] 


\section{Tab. 2: Criteria of sustainable urban construction - Part 2}

\begin{tabular}{c|l|l}
\multicolumn{1}{c|}{ No. } & \multicolumn{1}{c}{ Name of criterion } & \multicolumn{1}{c}{ Description of a criterion and the direction for assessment } \\
\hline Environmental & $\begin{array}{l}\text { Urban area, sq. } \mathrm{km} ; \\
{[31]}\end{array}$ & $\begin{array}{l}\text { Describes the size of a city, including the central part and suburbs that fall within the jurisdiction } \\
\text { of the city municipality. } \\
\text { Direction - maximisation (aimed at covering the greatest possible urban area with sustainability } \\
\text { principles). }\end{array}$ \\
\hline $\mathrm{x}_{9}$ & $\begin{array}{l}\text { Area of buildings in the } \\
\text { urban area, \%; } \\
{[31]}\end{array}$ & $\begin{array}{l}\text { Defines the part of urban territory, which is occupied by buildings. The criterion assess the } \\
\text { potential for construction of new buildings or other structures. } \\
\text { Direction - minimisation (assessing reserves of potential for a wider development). }\end{array}$ \\
\hline $\mathrm{x}_{10}$ & $\begin{array}{l}\text { Office and production } \\
\text { space, } \\
\text { Thousands sq. } \mathrm{m} ;[23]\end{array}$ & $\begin{array}{l}\text { Criterion that describes the area of buildings used for office space, production, storage and other } \\
\text { industrial purposes. } \\
\text { Direction - minimisation (assessing the development potential of larger construction businesses). }\end{array}$ \\
\hline & \multicolumn{2}{|c|}{$\begin{array}{l}\text { Criterion that defines urban air pollution. Air pollution is determined by way of assessing the } \\
\text { concentration of substances such as carbon dioxide, ozone, nitrogen dioxide, sulfur dioxide and } \\
\text { other gasses in air. Direction - minimisation (aimed at clean environment). }\end{array}$} \\
\hline
\end{tabular}

Source: own and [9], [22], [23], [24], [31].

\section{Fig. 1: Distribution of residents at a distance of $300 \mathbf{~ k m}$}

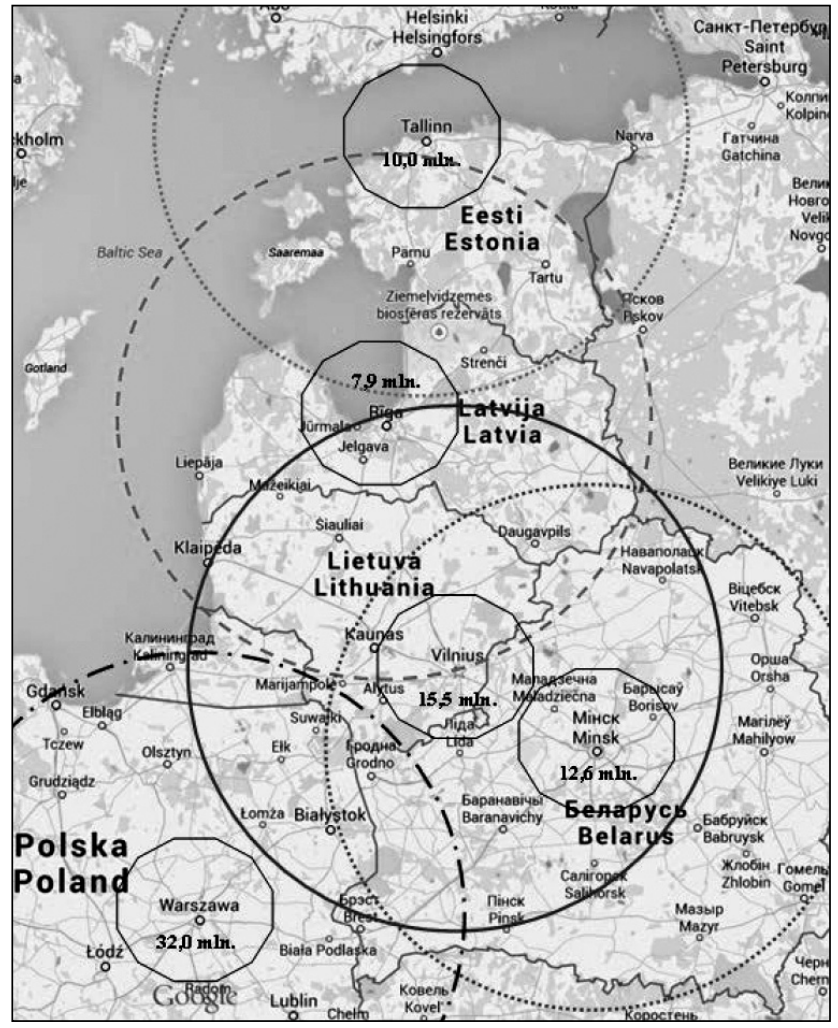


The listed criteria comprise a calculation system, which is described as a multi-criteria problem. Research literature suggests numerous algorithms that could be used to solve such problems, e.g. MOORA, MULTIMOORA, TOPSIS, VIKOR, ELECTRE, PROMETHEE, ARAS, COPRAS, SAW and other methods that are widely used around the globe.

Urban environments interact with numerous stakeholders [15]. Vilnius, Riga and Tallinn as well as their surrounding territories are no exception as their residents feel the impact of large cities (Fig. 1). The interacting environment of these cities is closely linked with state authorities, business entities, religious communities, investors, residents and foreign tourists.

Nature and civilisation dwell in close interaction with each other, which must be maintained considering interests of all stakeholders [30]. Aiming to satisfy needs of a number of stakeholder groups, certain calculation methods have to be used in order to assess the input of each group into decision-making. Aiming to assess effectiveness of a city while interacting with private investors and striving for a coherent balance among principles, assessment criteria listed in Tab. 2 are used to solve this problem, i.e. complex implementation of a construction project [18]:

- Expansion of green spaces and biodiversity;

- Compactness and variety of urban public spaces;

- Development of the public transport system;

- Determining environmental quality and a healthy city;

- The use of renewable energy sources;

- Waste sorting and promotion of waste-sorting culture;

- Promotion of social life and interaction;

- Regulating activities of business entities on the basis of sustainable development principles;

- Education on sustainable development;

- International cooperation of cities;

- Adherence to above-named strategies.

\section{The Problem Solving Process}

This problem has been designed following the assessment of three alternatives, which are described with the help of certain criteria. To solve this multi-criteria problem, MOORA and MULTIMOORA have been used.

While determining maximising and minimising directions of criteria for MOORA and MULTIMOORA alternatives, the authors of the article assessed these directions in relation to interests of private investors and residents, i.e. aiming for general principles of sustainable development: promotion of business, satisfaction of needs of the public and humans, and saving nature and resources.

\subsection{Problem Solving with the Help of MOORA Method}

MOORA method (Multi-Objective Optimization On the basis of Ratio Analysis) was first introduced in 2006, by researchers Brauers and Zavadskas [6], [19]. MOORA method has been used in various research areas, e.g. engineering [27], [26], [14], economics [25], [3], [28], management [4], environmental protection [16], [17] and production [8].

MOORA method is comprised of two parts [6] that control each other:

- the Ratio System; and

- the Reference Point.

According to [8], MOORA method can be easily understood and implemented. Calculation principles and results using MOORA method are provided in Tab. 3 .

\subsection{Problem Solving with the Help of MULTIMOORA Method}

MULTIMOORA is the method designed on the basis of MOORA by adding one more multiplicative form [7]. The schematic expression of the method is provided in Fig. 2. 


\section{Fig. 2: MULTIMOORA decision algorithm}

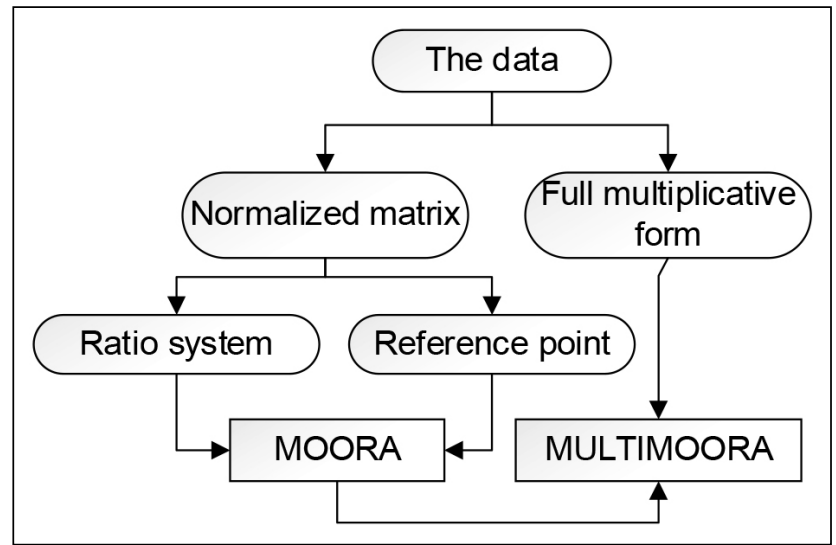

Source: [7]

MOORA method was supplemented with full multiplicative form, which comprises minimisation and maximisation of the multiplicative utility function. On the basis of data provided in Tab. 3, MULTIMOORA calculations are made. The overall utility of the $i$-th alternative can be expressed as a value that has no measure:

$$
U_{i}^{\prime}=\frac{A_{i}}{B_{i}},
$$

where $A_{i}=\prod_{j=1}^{g} x_{i j}, i=1.2 \ldots . \mathrm{m}$ denotes the product of objectives of the $i$-th alternative to be maximized with $\mathrm{g}=1 \ldots . . \mathrm{n}$ as the number of objectives to be maximized.
And $B_{i}=\prod_{j=q+1}^{n} x_{i j}$ denotes the product of objectives of the $i$-th alternative to be minimized with $n-g$ as the number of objectives (indicators) to be minimized.

\subsection{Assessment of Results}

Summary of results received using MOORA and MULTIMOORA calculation methods (Tab. 4) demonstrated that considering the currently prevailing conditions in the Baltic states and aiming to develop sustainable construction in the region, the most attractive investment zone is the city of Vilnius (Lithuania), i.e. alternative $a_{1}$.

\section{Tab. 4: Calculation results}

\begin{tabular}{c|c|c|c|c|c} 
& \multicolumn{3}{|c|}{ MULTIMOORA } & \multirow{2}{*}{$\begin{array}{c}\text { The sum of } \\
\text { rank }\end{array}$} & Final rank \\
\cline { 2 - 3 } & $\mathrm{RS}$ & $\mathrm{RP}$ & $U_{i}$ & 3 & $\mathbf{1}$ \\
\cline { 2 - 3 } $\mathrm{a}_{1}$ & 1 & 1 & 1 & 9 & $\mathbf{3}$ \\
\hline $\mathrm{a}_{2}$ & 3 & 3 & 3 & 6 & $\mathbf{2}$ \\
\hline $\mathrm{a}_{3}$ & 2 & 2 & 2 & \\
\hline
\end{tabular}


Tab. 3: MOORA and MULTIMOORA decision algorithm

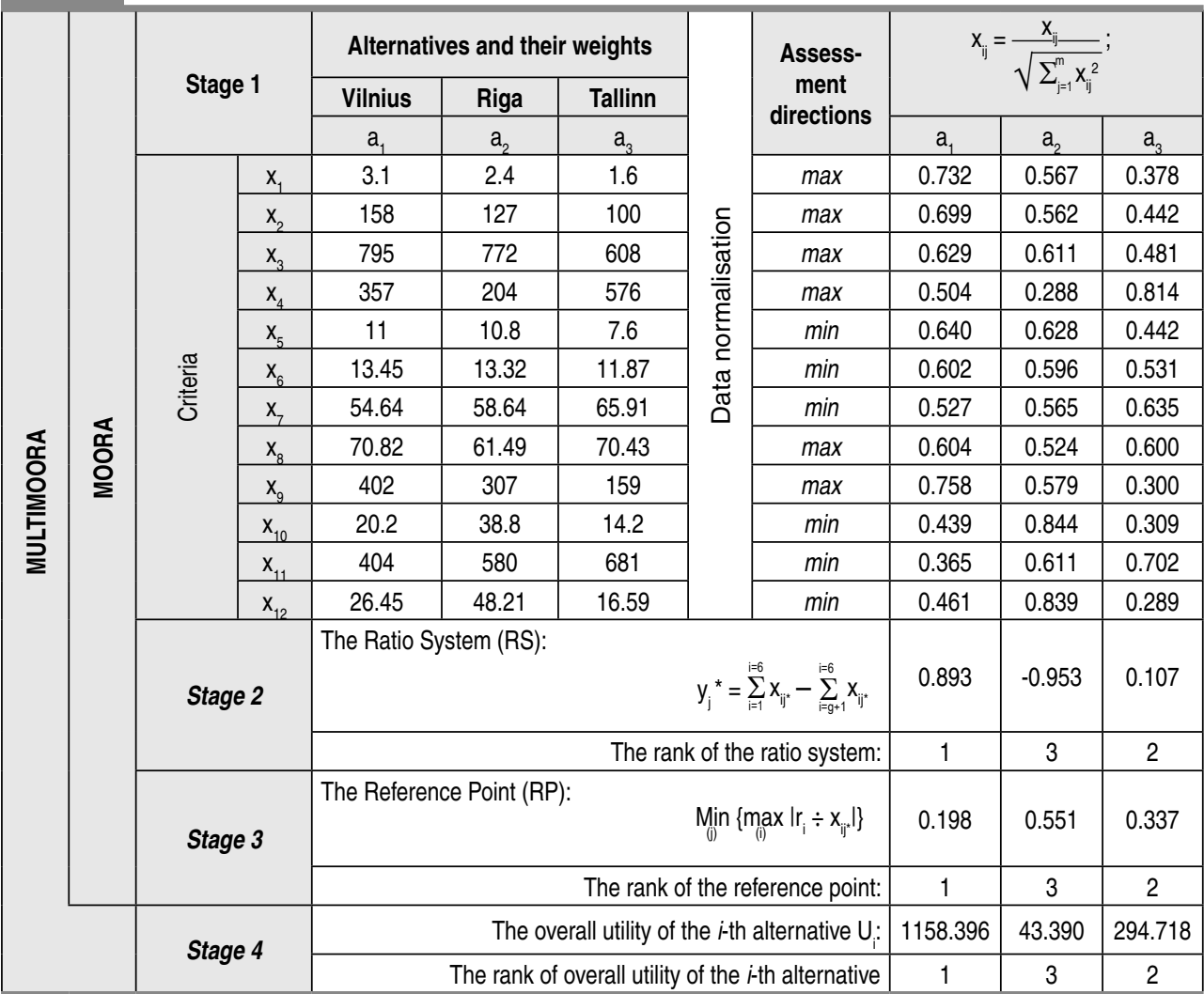

Source: own

\section{Conclusions}

Each true-life situation, which requires decision-making, requires to carefully consider the available information. The objective of this article was to assess the potential of construction development in the Baltic states - Lithuania, Latvia and Estonia - and rank these capital cities in terms of their attractiveness. Certainly, criteria that define the alternatives could be supplemented with other criteria that are important for decision-making groups.

As mentioned before, the assessment has been carried out to promote private investments following the principles of sustainable development, to ensure the union between private business objectives, regulation by state authorities and satisfaction of interests of urban residents. A number of descriptive criteria - comprising a multi-criteria problem, which has been assessed using weightless MOORA and MULTIMOORA methods - have been used to describe the alternatives. Following the assessment of criteria systems, the conclusion was made that considering the market trends and the ideology of sustainable development, the zone of the city of Vilnius (Lithuania) is the most attractive for investments as well as the development of construction business.

\section{References}

[1] KANG ANGELOPOULOU, E., BALFOUSSIA, H., GIBSON, H. D. Building a financial conditions index for the euro area and selected euro area countries: What does it tell us about the crisis? Economic Modelling. 2014, Vol. 38, pp. 392-403. ISSN 0264-9993. DOI: 10.1016/j. econmod.2014.01.013. 
[2] AUERBACH, A. J., GALE, W. G., HARRIS, B. H. Activist Fiscal Policy. Journal of Economic Perspectives. 2010, Vol. 24, Iss. 4, pp. 141-163. ISSN 0895-3309. DOI: 10.1257/jep.24.4.141.

[3] BALEŽENTIS, T., MISIŪNAS, A., BALEŽENTIS, A. Efficiency and productivity change across the economic sectors in Lithuania (2000-2010): the DEAMULTIMOORA approach. Technological and economic development of economy. 2013, Vol. 19, pp. 191-213. ISSN 2029-4913. DOI: 10.3846/20294913.2013.881431.

[4] BALEŽENTIS, T., ZENG, S., BALEŽENTIS, A. MULTIMOORA-IFN: a MCDM method based on intuitionistic fuzzy number for performance management. Economic Computation and Economic Cybernetics Studies And Research. 2014, Vol. 48, Iss. 4, pp. 85-102. ISSN 0424-267X. [5] BAUMGÄRTNER, S., QUAAS, M. F. What is sustainability economics? Ecological Economics. 2010, Vol. 69, Iss. 3, pp. 445450. ISSN 0921-8009. DOI: 10.1016/j. ecolecon.2009.11.019.

[6] BRAUERS, W. K. M., ZAVADSKAS, E. K. The MOORA method and its application to privatization in a transition economy. Control and Cybernetics. 2006, Vol. 35, Iss. 2, pp. 445469. ISSN 0324-8569.

[7] BRAUERS, W. K. M., ZAVADSKAS, E. $\mathrm{K}$. Project management by MULTIMOORA as an instrument for transition economies. Technological and Economic Development of Economy. 2010, Vol. 16, Iss. 1, pp. 5-24. ISSN 2029-4913. DOI: 10.3846/tede.2010.01.

[8] CHAKRABORTY, S. Applications of the MOORA method for decision making in manufacturing environment. The International Journal of Advanced Manufacturing Technology. 2011, Vol. 54, Iss. 9-12, pp. 1155-1166. ISSN 0268-3768. DOI: 10.1007/s00170-010-2972-0.

[9] DNB. Macroeconomic forecasts for Baltic countries [online]. Vilnius: DNB, 2014 [cit. 2014-12-28]. Available from: https://www.dnb. It/lt/apzvalgos/baltijos-saliu-makroekonominesprognozes.

[10] General plan of Vilnius City in 2015 year [online]. Vilnius: Vilnius City, 2014 [cit. 201412-28]. Available from: http://www.vilnius.lt/lit/ Vilniaus_miesto_bendrasis_planas/.

[11] HALL, R. E. Why Does the Economy Fall to Pieces after a Financial Crisis? Journal of Economic Perspectives. 2010, Vol. 24, Iss. 4, pp. 3-20. ISSN 0895-3309. DOI: 10.1257/ jep.24.4.3.
[12] KAKLAUSKAS, A., et al. Crisis management in construction and real estate: Conceptual modeling at the micro-, mesoand macro-levels. Land Use Policy. 2011, Vol. 28, Iss. 1, pp. 280-293. ISSN 0264-8377. DOI: 10.1016/j.landusepol.2010.06.008.

[13] KANG, H. H., LIU, S. B. The impact of the 2008 financial crisis on housing prices in China and Taiwan: A quantile regression analysis. Economic Modelling. 2014, Vol. 42, pp. 356-362. ISSN 0264-9993. DOI: 10.1016/j. econmod.2014.07.018.

[14] KILDIENE, S. Assessment of Opportunities for Construction Enterprises in European Union Member States Using the MULTIMOORA Method. Procedia Engineering. 2013, Vol. 57, pp. 557-564. ISSN 1877-7058. DOI: 10.1016/j. proeng.2013.04.071.

[15] KUTUT, V., ZAVADSKAS, E. K., LAZAUSKAS, M. Assessment of priority alternatives for preservation of historic buildings using model based on ARAS and AHP methods. Archives of Civil and Mechanical Engineering. 2014, Vol. 14, Iss. 2, pp. 287-294. ISSN 16449665. DOI: 10.1016/j.acme.2013.10.007.

[16] LIU, H.-C., FAN, X.-J., LI, P., CHEN, Y.$Z$. Evaluating the risk of failure modes with extended MULTIMOORA method under fuzzy environment. Engineering Applications of Artificial Intelligence. 2014, Vol. 34, pp. 168-177. ISSN 0952-1976. DOI: 10.1016/j. engappai.2014.04.011.

[17] LIU, H.-C., YOU, J.-X., LU, C., SHAN, M.-M. Application of interval 2-tuple linguistic MULTIMOORA method for health-care waste treatment technology evaluation and selection. Waste Management. 2014, Vol. 34, Iss. 11, pp. 2355-2364. ISSN 0956-053X. DOI: 10.1016/j. wasman.2014.07.016.

[18] MARSAL-LLACUNA, M. L., COLOMERLLINAS, J., MELENDEZ-FRIGOLA, J. Lessons in urban monitoring taken from sustainable and livable cities to better address the Smart Cities initiative. Technological Forecasting \& Social Change. 2015, Vol. 90, pp. 611-622. ISSN 00401625. DOI: 10.1016/j.techfore.2014.01.012.

[19] MASRI, H. Quantitative economics as a scientific approach to the solution of problems of a complex nature - in honor of professor Willem Karel M. Brauers on the occasion of his 90th birthday. Technological and Economic Development of Economy. 2014, Vol. 20, Iss. 3, pp. 590-600. ISSN 2029-4913. DOI: $0.3846 / 20294913.2014 .966350$. 
[20] MAYER, A. L. Strengths and weaknesses of common sustainability indices for multidimensional Systems. Environment International. 2008, Vol. 34, Iss. 2, pp. 277291. ISSN 0160-4120. DOI: 10.1016/j. envint.2007.09.004.

[21] MISHKIN, F. S. Over the Cliff: From the Subprime to the Global Financial Crisis. Journal of Economic Perspectives. 2011, Vol. 25, Iss. 1, pp. 49-70. ISSN 0895-3309. DOI: 10.1257/ jep.25.1.49.

[22] NUMBEO. Cost of Living [online]. Belgrade: NUMBEO, 2014 [cit. 2014-12-28]. Available from: http://www.numbeo.com/.

[23] PWC. Real Estate Market Report 2013 [online]. Ober-Haus, 2013 [cit. 2015-01-04]. 108 p. (PDF). Available from: http://www.pwc.com/ It/en/assets/publications/ober-haus_market_ report_baltic_states_2013.pdf.

[24] SORAINEN [online]. [cit. 2014-12-28]. Available from: http://www.sorainen.com/ UserFiles/.../INREAL_2013-2014_NT_ Ap\%C5\%BEvalga.pdf.

[25] STANKEVIČIENĖ, J., SVIDERSKE், T., MIEČINSKIENE், A. Dependence of sustainability on country risk indicators in EU Baltic sea region countries. Journal of Business Economics and Management. 2014, Vol. 15, Iss. 4, pp. 646-663. ISSN 2029-4433. DOI: 10.3846/16111699.2014.965555.

[26] STANUJKIC, D. An extension of the MOORA method for solving fuzzy decision making problems. Technological and Economic Development of Economy. 2013, Vol. 19, pp. 228-255. ISSN 2029-4913. DOI: 10.3846/20294913.2013.880083.

[27] STANUJKIC, D., et al. An efficient and simple multiple criteria model for a grinding circuit selection based on MOORA Method. Informatica. 2014, Vol. 25, Iss. 1, pp. 73-93. ISSN 0868-4952.

[28] STREIMIKIENE, D., BALEZENTIENE, L. Comparative assessment of heat generation technologies in district heat sector of Lithuania. Transformations in Business \& Economics. 2014, Vol. 13, Iss. 2, pp. 161-173. ISSN 16484460.

[29] TAYLAN, O., BAFAIL, A. O., ABDULAAL, R., KABLI, M. R. Construction projects selection and risk assessment by fuzzy AHP and fuzzy TOPSIS methodologies. Applied Soft Computing. 2014, Vol. 17, pp.105-116. ISSN 1568-4946. DOI: 10.1016/j.asoc.2014.01.003.

[30] TURSKIS, Z., LAZAUSKAS, M., ZAVADSKAS, E. K. Fuzzy Multiple Criteria Assessment of Construction Site Alternatives for Non-Hazardous Waste Incineration Plant in Vilnius City, Applying ARAS-F and AHP Methods. Journal of Environmental Engineering and Landscape Management. 2012, Vol. 20, Iss. 2, pp.110-120. ISSN 1648-6897. DOI: 10.3846/16486897.2011.64582.

[31] WIKIPEDIA [online]. Wikimedia Foundation, c2014 [cit. 2014-12-28]. Available from: en.wikipedia.org/.

\section{Prof. Edmundas Kazimieras Zavadskas,} PhD, DSc, Dr h. c. multi

Vilnius Gediminas Technical University Department of Construction Technology and Management edmundas.zavadskas@vgtu.It

Assoc. Prof. Jonas Šaparauskas, Ph.D.

Vilnius Gediminas Technical University Department of Construction Technology and Management jonas.saparauskas@vgtu.It

\section{Marius Lazauskas}

Vilnius Gediminas Technical University Department of Construction Technology and Management marius.lazauskas@gmail.com 


\section{Abstract}

\section{RANKING OF PRIORITIES AMONG THE BALTIC CAPITAL CITIES FOR THE DEVELOPMENT OF SUSTAINABLE CONSTRUCTION}

\section{Marius Lazauskas, Edmundas Kazimieras Zavadskas, Jonas Šaparauskas}

Crisis of the real estate sector resulted in disadvantageous conditions for legal entities operating in the field of construction and implementation of new property development projects. As a result, many such entities started investigating their options to offer construction services and products to more economically attractive foreign markets. This necessitates the need to assess the effectiveness of investments into new markets, considering the current developmental trends of the construction sector, which are related to implementation of sustainable construction projects. Close cooperation of Baltic States at the national level and joint activities of several construction market participants predetermine the necessity to assess biggest cities of Lithuania, Latvia, and Estonia being the potential market of construction sector to be selected as a target segment of efficient development of construction needs. These are the reasons behind the creation of a typical calculation model, which could be adapted for an effective and uncomplicated assessment of investment rationale in new markets while ensuring the adherence to principles of sustainable development. Assessment of potential capabilities of a construction sector of three Baltic capitals (Vilnius, Riga, Tallinn) could provide the opportunity to direct capital and investments of construction market participants in the wore efficient way and create the highest added value for the economy, residents and development of sustainable environments. Identification of project implementation area is a key factor in determining directions of the activity performed by private investors, performed in order to assess the opportunity of efficient realisation of construction project proposed for implementation with particular environment. A multiple-criteria task is formulated, which aims to determine the rank of priorities among cities of the Baltic states; and multi-criteria methods MOORA and MULTIMOORA are used for decision-making.

Key Words: Real estate, construction market, decision-making, MOORA, MULTIMOORA.

JEL Classification: CO2, R4, L62, L92.

DOI: 10.15240/tul/001/2015-2-002 